\title{
Selenomethionine: A Therapeutic Adjunct To Arsenic-Free Water In Reducing Tissue Arsenic Load
}

\author{
Morshed Nasir ${ }^{1}$, Mir Misbahuddin ${ }^{2}$, S M Keramat $\mathrm{Ali}^{3}$
}

\begin{abstract}
The study was designed to evaluate the accumulation of arsenic in different tissues and the effect of selenium supplement to counteract the shanges of arsenic levels in rat model. Adult rats of same age and weight were divided into five grostps and housed in individual cages. Group ' $A$ ' was considered as control having normal diet and water ad libitum. Grosp ' $B$ ' received arsenic triaxide solution orally at the dose of $0.4 \mathrm{mg} / \mathrm{kg}$ body at. for three months. Group ' $\mathrm{C}$ ' received selenomethionine at $20 \mu \mathrm{g}$ single dose daily for three months mixed with normal dict. Group ' $D$ ' recrived arsenic added sater for two months and then arsenic free water for last one month. Grosp ' $E$ ' received arsenic added water for two months and then selenium added diet for last one month. Total As concentrations in liver, spleen, kidney, beart, lungs, intestine and brain were estimated by spectropborometer using SDDC-arsine complex. The total As concentrations in Gronp ' $B$ ' were found significantly $(P<0.001)$ bigher in comparison to control. After recriving selenium-added diet for one montb, tissue As levels avere reduced comparing to the arsenic intaxicated Group. The role of selenium was particularly enaluated by comparing the values to the group witbout baning selenium-added diet after arsenic accumulation and selenitum was foond to be effectise in reduaing the accumulation of arsenic in different tissues of rat affer ensuning arsenic free water.
\end{abstract}

\section{Introduction}

Exposure to arsenic adversely affects multiple organ systems. Following ingestion, arsenic is absorbed and distributed widely to almost all tissues of the body e.g. liver, spleen, kidney, heart, lungs, intestine, brain, muscle and thyroid gland'. The toxicity of arsenic compound depends on the amount, duration and the chemical and physical form of arsenic e.g. trivalent and inorganic arsenic is more toxic than pentavalent and organic arsenic ${ }^{2}$. The adverse health effects of arsenic may be transferred to the gencrations to come, as the trans-placental crossing has been

1. Assistant Professor, Department of Pharmacology and Therapeutics, HFRCMC, Dhaka.

2. Professor and Chairman, Department of Pharmacology, BSMMU, Dhaka.

3. Professor, Clinical Nutrition, Institute of Nutrition and Food Science, University of Dhaka. demonstrated in both experimental animals and human ${ }^{3}$. Moreover, the people already ingested arsenic contaminated water throughout the unknown years is highly vulnerable to various diseases including cancers to various extant. Therefore, it becomes obvious to search for a curative treatment to reduce accumulation of arsenic in various organs.

Selenium is an essential element needed in trace amount for the biosynthesis of many enzymes playing vital role in oxidative function. It cannot be synthesized within the body and must be supplied exogenously through food. Clinical deficiency disease responsive to selenium in human beings is Keshan disease, a cardiomyopathy observed in china. Low plasma selenium levels also have been noted in colonic, gastric and pancreatic carcinoma, cirrhosis, burns and kwashiorkor. Premature infants and adults sustained on parenteral or enteral solutions devoid of 
selenium are at risk of deficiency characterized by cardiomyopathy, growth retardation, cataract formation, abnormal placenta retention, deficient spermatogenesis, and dystrophic changes in skeletal muscle ${ }^{4}$. In patient with black-foot disease, selenium concentration was reported to be decreased in comparison to the normals.

It is well documented that arsenic, gold, platinum significantly influences the fate of exogenous selenium, whereby they may adversely affect the availability of this essential element for the synthesis of selenoenzymes ${ }^{6}$. Arsenic and selenium are the metalloids with similar chemical properties and metabolic fates. Therefore, selenium is an important element for the synthesis and activity of the enzymes inhibited by arsenicals.

\section{Methodology}

The study was carried out at the Department of Pharmacology and Toxicology, Bangabandhu Sheikh Mujib Medical University (BSMMU). Forty adult Long Evans rats of same age, weighing $230-250 \mathrm{gm}$. were divided in to six groups and housed in individual cages with proper matting in 12 hours of light and dark schedule. Group A received de-ionized water and normal diet ad libitum for three months and considered as control. Group B received arsenic (tri-oxide) added discilled water at the dose of $400 \mu \mathrm{g} / \mathrm{kg}$ body wt./day orally for three months and considered as arsenic intoxicated. Group $C$ received selenomethionine at the dose of $20 \mu \mathrm{g}$ daily mixed with normal diet'. Group $D$ received arsenic added water for two months and arsenic-frec water for last one month and normal diet. Group $\mathrm{E}$ received arsenic added water for two months followed by seleniumadded diet for last one month.

The selenomethionine was obtained from "Selenomax" containing high sclenium yeast rich in L-selenomethionine. All the rats were sacrificed on the $91 \mathrm{st}$ day and liver, spleen, kidneys, heart, lungs, intestine and brain were collected and preserved.

Concentrations of arsenic were estimated after digestion of specimen tissues with strong acids. The trivalent inorganic arsenic was reduced to arsine $\left(\mathrm{AsH}_{3}\right)$ after treated with zinc in strong acid solution in an arsine generator. The arsine was then passed through a scrubbcr containing glass wool moistened with lead acetate and into an absorber tube containing Silver Diethyl Dithio Carbamate (SDDC) dissolved in pyridine. The arsine reacted with the silver salt, forming a soluble red complex suitable for photometric measurement ${ }^{8,9}$.

\section{Results}

Concentrations of total arsenic in tissues:

After 90 days of drinking arsenic added water, the mean $( \pm S E)$ arsenic level in the rats of 'Group B' were increased significantly $(\mathrm{P}<0.001)$ in comparison to 'Group $\mathrm{A}$ ' (control) in all the tissues examined. Highest level was found in the spleen $54.2 \mu \mathrm{g} / \mathrm{gm}$ of tissue and the lowest level in the brain $16.0 \mu \mathrm{g} / \mathrm{gm}$ of tissue. In the rats of 'Group $C^{\prime}$ ', which were fed on selenium added diet without arsenic added water; there were no significant changes in arsenic levels in comparison to the control.

Tissue arsenic levels were found reduced in rats of 'Group D' after getting normal diet and arsenic-free water for the last 30 days after intoxication. In the rats of 'Group E' that were treated with selenium added diet for last 30 days after arsenic intoxication, the concentrations of arsenic were found significandly $(\mathrm{P}<0.001)$ lower in all seven organs in comparison to 'Group B' and 'Group D'. In every group the tissue distribution pattern of arsenic is almost similar with highest accumulation in the spleen and lowest in the brain (Table I, Fig). 


\begin{tabular}{|l|c|c|c|c|c|c|c|}
\hline $\mathrm{n}=40$ & Spleen & Liver & Kidney & Lung & Heart & Intestine & Brain \\
\hline Group-A & 7.6 & 3.9 & 5.2 & 4.6 & 2.0 & 1.4 & 0.5 \\
& \pm 0.2 & \pm 0.3 & \pm 0.1 & \pm 0.2 & \pm 0.1 & \pm 0.1 & \pm 0.1 \\
\hline Group-B & 54.2 & 29.3 & 36.9 & 40.0 & 3.1 .3 & 3.6 & 16.0 \\
& \pm 2.7 & \pm 1.2 & \pm 1.9 & \pm 0.4 & \pm 1.1 & \pm 0.9 & \pm 0.7 \\
\hline Group-C & 8.0 & 4.1 & 5.9 & 4.3 & 1.8 & 1.7 & 0.8 \\
& \pm 0.3 & \pm 0.2 & \pm 0.4 & \pm 0.3 & \pm 0.2 & \pm 0.1 & \pm 0.1 \\
\hline Group-D & 28.3 & 20.0 & 26.1 & 21.0 & 18.6 & 14.7 & 10.9 \\
& \pm 1.0 & \pm 1.5 & \pm 1.2 & \pm 0.6 & \pm 0.8 & \pm 1.0 & \pm 0.8 \\
\hline Group-E & 16.6 & 10.5 & 12.5 & 1.3 .4 & 10.7 & 9.4 & 8.3 \\
& \pm 0.7 & \pm 0.4 & \pm 0.4 & \pm 0.4 & \pm 0.7 & \pm 0.6 & \pm 0.7 \\
\hline
\end{tabular}

Table I. Concentration of totai arsenic in $\mu \mathrm{g} / \mathrm{gm}$ of tissue in different organs

Note: Group $-A=$ normal diet and water. Group $-B=$ normal diet and arsenic added for threc months. Group- $\mathrm{C}=$ selenium added diet for three months. Group-D $=$ arsenic added water for two months and normal diet and water for last one month. Group-E $=$ arsenic added water for two months and selenium added diet for last one month. $\mathrm{n}=$ number of animal (rat)

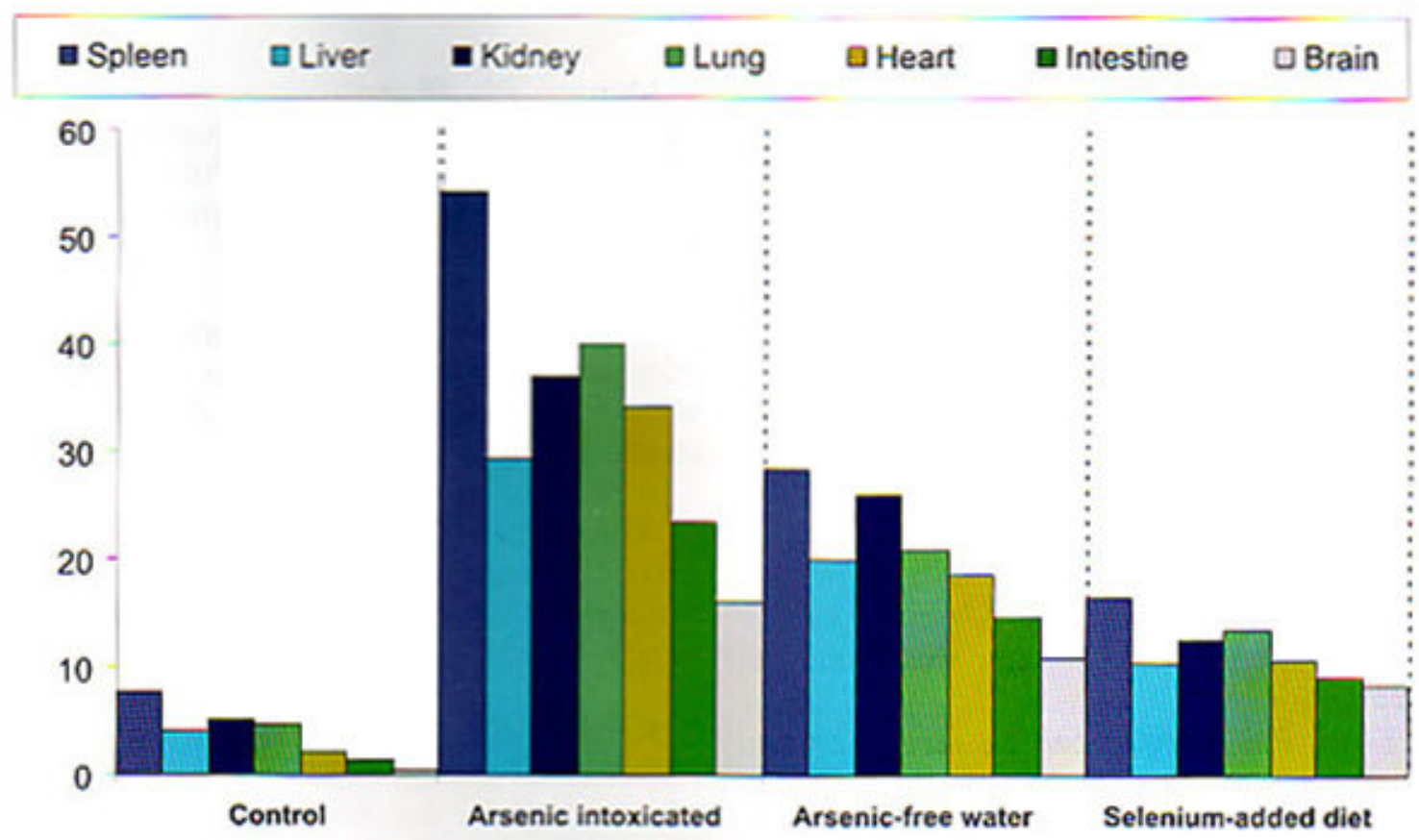

Fig : Trend of reduction of accumulated total arsenic in different tissues with or without selenomethionine over arsenic-free water. 


\section{Discussion}

The interaction between arsenic and selenium was reported by Levander as arsenite stimulated the excretion of selenium in to the bile, so did selenite stimulated the excretion of arsenic. Kenyon et al reported in 1997 that arsenic and selenium might combine in liver to form 'detoxification conjugate' and enhance biliary excretion. Moreover, arsenic and selenium are metalloids with similar chemical properties that may compete for a common sulfhydryl (-SH) group. So it is possible that arsenic elimination is delayed in selenium deficiency because there could be more target -SH groups for arsenic to react with ${ }^{7}$. According to the ccllular mechanism of arsenic toxicity, it is almost evident of the inactivation or suppression of antioxidant enzymes containing selenium and glutathione as a structural component or cofactor i.c. glutathione peroxidase, glutathione reductase, methyl transferase etc. Selenium acts as an acceptor of biogenic methyl groups and is involved in the detoxification of metals and certain xenobiotics ${ }^{10}$. In an experiment on rat, it was observed that the hepatic glutathione peroxidase activity was depressed following selenium deficiency which is a vital antioxidant enzyme involved in arsenic induced toxicity ${ }^{11}$. This enzyme activity was restored completely after supplementation of $40 \mathrm{ppm}$ dietary selenium in a study by Ip and Ganther ${ }^{12}$. In this study accumulation of arsenic in tissues were reduced after supplementation of selenium that may correlate the restoration of enzyme activity to detoxify arsenic. In this study, the highest amount of arsenic is found accumulated in spleen followed by lung, kidney, heart, intestine, liver, and brain. This finding has similarity to the observations of Gregus and Klassen (1986) except for kidney in which arsenic was found in highest amount.

From this study it can be assumed that though only arsenic-free water showed to decrease the concentrations of accumulated arsenic in different tissues but the supplementation of selenium along with the arsenic-free water was statistically more significant $(P<0.001)$ in reduction of arsenic levels.

\section{Conclusion}

From this study it can be concluded that arsenic can be accumulated in almost all vital organs of the body namely liver, spleen, kidncy, heart, lungs, intestine and brain. It can also be concluded that the dietary supplementation of selenomethionine may be considered as an important adjunct in reducing tissue arsenic levels even after ensuring arsenic free water.

\section{References}

1. Gregus $Z$ and Klassen CD. Disposition of metals in rats: A comparative study of faecal, urinary and biliary excretion and tissuc distribution of eighteen metals. Toxicol $A \mathrm{ppl}$ Pharmacol. 1986; 85: 24-38.

2. Khan AW. Arsenic in drinking water: Health effects and management. Dept.of Occupational and Environmental Health. 1997; pp 1-47.

3. W.H.O. Environmental Health Criteria-18. Pub: UNEPA, ILO, WHO, Geneva. 1981; PP 13-46.

4. Munson PL. Pharmacology of nutrients and nutritional diseases: microminerals. In: Principles of Pharmacology. Pub: Chapman \& Hall, New York. 1996; 1st edition: pp $1007-$ 1011 .

5. Wang CT. Concentrations of arsenic, selenium, zinc, iron and copper in the urine of black-foot disease patients at different clinical stages. Eur J Clin Chem. 1996; 34: 493-496.

6. Gregus Z, Gyurasics A and Csanaky I. Effects of arsenic, platinum and gold containing drugs on the disposition of exogenous selenium in rats. Toxicol Sci 2000; 57: 22-31.

7. Kenyon EM, Hughes MF and Levander $\mathrm{OA}$. Influence of dietary selenium on the disposition of arsenate in the female B6C3F1 mouse. J Toxicol Environ Health. 1997; 51: 279-299.

8. Bauer JD. Toxicology and therapeutic drug monitoring. In : Clinical laboratory methods. Pub : The C.V.Mosby Company, Missouri. 1990; 9th edition: pp 664-665. 
9. Sedlak J and Lindsay RH. Estimation of total, protein-bound and non-protein sulfhydryl groups in tissue with Ellman's reagent. Anal Biochem. 1968; 25: 192-205.

10. Schrauzer GN. Selenium: mechanistic aspects of anticarcinogenic action. Biol Trace Elem Res. 1992; 33: 51-62.

11. Turan B, Acan NL, Ulusu NN and Tezcan EF. A comparative study on effect of dietary selenium and vitamin $E$ on some antioxidane enzyme activities of liver and brain tissues. Biol Trace Elem Res. 2001; 81: 141-152.

12. Ip $\mathrm{C}$ and Ganther HE. Biological activities of trimethylselenomethonium as influenced by arsenite. J Inorg Biochem. 1992; 46: 215-222. 